\title{
Investigation and Analysis of Knowledge, Ability, and Quality Requirement of Applied International Logistics Skilled Talents*
}

\author{
Yuanqing $\mathrm{Hu}$ \\ Hunan Modern Logistics College \\ Changsha, China 410131
}

\author{
Xinming Tan \\ Hunan Modern Logistics College \\ Changsha, China 410131
}

\begin{abstract}
With the development of economic globalization, the status of international logistics in the national economic system has become increasingly important. At present, the structural shortage of high-quality application-oriented international logistics talents has become increasingly prominent and has become a bottleneck restricting the development of China's logistics industry. Starting from the training of application-oriented international logistics talents, this paper discusses the knowledge, ability and quality needs of application-oriented international logistics talents and analyzes them, providing a reference for the reform of the training model of application-oriented international logistics talents.
\end{abstract}

Keywords-export-oriented enterprises; international logistics; innovation trends

\section{INTRODUCTION}

Since the Twelfth Five-Year Plan, China's open economy has achieved rapid development: foreign trade has grown year by year; the strength of foreign-funded enterprises has increased; investment promotion platforms have expanded; and foreign economic cooperation has continued to expand. The development of export-oriented economy demands for outward-oriented talents increase synchronously from quantity to quality. With the accelerated pace of enterprises going abroad, the problem of shortage of outward-looking skilled talents has become increasingly prominent. Due to the wide range of foreign-related economy, the insufficient supply of complex-skilled talents required by enterprises for good foreign language skills, technical proficiency, and understanding of international communication rules is increasingly prominent.

\section{ECONOMIC GLOBALIZATION AND DEVELOPMENT OF INTERNATIONAL LOGISTICS}

As a supporting service industry for production and distribution, modern logistics must well adapt to the development trend of market internationalization and global economic integration. For higher vocational colleges that train application-oriented logistics management professionals, they should keep pace with the times and

*Fund: Project of the Social Science Achievement Review Committee of Hunan Province in 2018 (XSP18YBC074) create new teaching models and methods to meet the needs of an outward-oriented economy with rapid development for outward-oriented high-quality and application-oriented logistics professionals.

International logistics has developed along with the development of international trade and transnational operation. With the economic globalization, increasingly perfect infrastructure, and the rapid development of information technology, e-commerce logistics, green logistics, reverse logistics and outsourcing logistics have also become increasingly international. In this context, with the deepening of China's opening up to the outside world and the development of international economic and trade cooperation against the background of "the Belt and Road", the service support of international logistics has become increasingly important in China's national economic system, especially in the international trade. At the same time, with the deepening of world economic integration, a large number of transnational corporations have emerged. International production and international trade promoted and led by them have become the core force of economic globalization. It can be said that the internationalization of logistics is an inevitable requirement of economic globalization.

The modern international logistics industry is an emerging and composite industry across industries, sectors, and borders. The business covers production, distribution, transportation, agency, warehousing, information, customs clearance, commodity inspection, documents, insurance and many other fields. With the deepening of internationalization and globalization, both domestic companies, foreign companies and multinational companies have put forward higher and higher requirements for international logistics talents. Therefore, how to speed up the training of advanced applied international logistics talents, improve the training model of international logistics talents, improve the quality of training international logistics talents, and increase the capacity of effective talent output to meet the demand of the rapid development of social economy for the international logistics industry have become the fundamental task of training international logistics professionals in colleges and universities. 


\section{GENERAL PROFESSIONAL REQUIREMENTS (KNOWLEDGE, ABILITY, QUALITY) OF APPLICATION- ORIENTED TALENTS OF INTERNATIONAL LOGISTICS}

The so-called application-oriented talents mainly refer to the technical personnel, management personnel and senior technicians who can adapt to the actual job requirements and can handle front-line affairs to ensure the normal operation of production and operations. The main task of higher vocational education is to cultivate application-oriented technical talents who can adapt to the needs of the country's (regional) economic and social development. The education of application-oriented talents of international logistics majors in colleges and universities should not only be in line with social and market needs, but also should be based on the advantages and characteristics of colleges and universities. The professional setting of logistics majors should reflect the outward-oriented international career orientation. In other words, the setting of international logistics specialty in colleges and universities should be guided by the society's demand for international general logistics talents, with the purpose of cultivating compound modern logistics management professionals with solid professional skills, strong English ability, and good knowledge of international trade rules, especially WTO rules and convention. Its connotation should be embodied in the coordinated development of knowledge, ability and quality. In the process of revising the professional teaching plan, more attention should be paid to the cultivation of students' quality and ability, and the improvement of students' craftsman spirit, practical ability, innovation consciousness and other comprehensive qualities should be put through the whole process of teaching.

\section{A. Knowledge Structure}

1) Knowledge of international trade theory and practice: The talents should master international trade knowledge and international settlement knowledge, and be familiar with all aspects of the international trade process, and customs clearance operations, such as customs declaration, inspection, tax declaration, document delivery and other activities. The talents should also master the knowledge of customs declaration and inspection and the knowledge of international freight forwarding business. They must have the ability to correctly make out inspection forms and customs declaration forms, and be familiar with various operation procedures of cargo clearance.

2) Expertise in warehousing and transportation: The talents must be familiar with the operating procedures and rules of international multimodal transport, can design operational, safe, fast, cost-effective transportation schemes, and make overall arrangements for transportation modes, means of transportation, routes, personnel, etc. They have the ability to design reasonable international logistics transportation routes, select suitable means of transportation, handle special transportation and manage container yard.

3) Knowledge of financial cost management: Logistics services involve multiple links, including different costs and expenses. Logistics professionals should be familiar with the type, quantity and measurement of these costs, and have the knowledge of cost accounting and analysis of logistics project.

4) Safety management knowledge: International logistics involves multiple links and multiple modes of transport. There are many risks and hidden dangers in the operation process. Employees must have knowledge of safety management and cargo preservation, and take necessary risk prevention measures to protect the legitimate rights and interests of both parties.

5) Laws and regulation: It is required to be familiar with international conventions, international practices and international standards related to international logistics. The talents should be familiar with international trade rules, especially WTO rules, and be familiar with the laws and policies of different countries, that is, compliance education and risk control awareness education that are particularly emphasized in international business.

\section{B. Capability Structure}

1) English application ability: In daily communication, business document processing, business negotiation and contract signing, English is widely used in all aspects of international logistics activities. International logistics talents are not only able to communicate with customers orally and write accurate statements in English, but also have the ability to draft and design foreign language contracts.

2) Computer information technology application ability: Information system is the nerve center of the entire logistics operation system, which controls the effective operation of logistics. It is necessary to master modern computer information technology for the talents. Computer information technology can be comprehensively applied in logistics operations to improve the response speed and efficiency of the entire system.

3) Market observation and analysis capabilities: International logistics is the logistics that takes place between different countries in order to achieve international trade and transnational business activities between countries. This requires that international logistics professionals have a keen observation ability and accurate analysis ability to cope with changes in the international economic and political situation, prevent various risks, and make accurate judgments and decisions in a complex international economic background.

4) Marketing and customer service capabilities: The first and foremost task of working as an international logistics worker is to collect goods. Only being good at marketing business can international logistics companies carry out the next operation activities. This requires freight marketers to have proficient and comprehensive business knowledge, as well as good communication skills. The logistics customer service capabilities are increasingly 
attention to news, and learn about current events in international trade and international logistics. In the current curriculum system of logistics talents, education of transnational cultural content should be integrated.

During the survey of export-oriented enterprises, in order to analyze the needs of employers for specific international business capabilities, this questionnaire divided the degree of demand into great request, general request, and optional (Table I).

TABLE I. EMPLOYER'S DEMAND FOR SPECIFIC INTERNATIONAL LOGISTICS CAPABILITIES (80 QUESTIONNAIRES)

\begin{tabular}{|l|l|l|l|}
\hline \multicolumn{1}{|c|}{ Ability } & Great request & General request & Optional \\
\hline Import and export capacity & 33 & 50 & 0 \\
\hline Intercultural communication skills (foreign language application) & 21 & 55 & 4 \\
\hline Ability to analyze international business environment & 16 & 44 & 20 \\
\hline Product brand development and management capabilities & 34 & 45 & 1 \\
\hline International market risk prevention ability & 40 & 37 & 3 \\
\hline International sales channel development and control capabilities & 48 & 31 & 1 \\
\hline transnational operation capacity & 20 & 38 & 22 \\
\hline Investment and financing capabilities in overseas markets & 15 & 35 & 30 \\
\hline
\end{tabular}

From the results of the questionnaire, export-oriented units still believe that import and export business capabilities and foreign language communication applications are the core competencies that international logistics students must master. At the same time, as international economic and trade activities of enterprises gradually rise to the stage of exporting their own brands, there is a strong demand for the talents with relevant international business ability.

TABLE II. EMPLOYER'S SELECTION OF IMPORT AND EXPORT BUSINESS CAPABILITIES (80 QUESTIONNAIRES)

\begin{tabular}{|l|l|l|l|}
\hline & \multicolumn{1}{|c|}{ Ranking the first } & \multicolumn{1}{|c|}{ Ranking the second } & \multicolumn{1}{c|}{ Ranking the third } \\
\hline The operation ability of each link of import and export & 32 & 36 & 12 \\
\hline Good operation of foreign language and oral English & 48 & 31 & 1 \\
\hline Good operation of electronic commerce and computer & 5 & 15 & 60 \\
\hline
\end{tabular}

Proficiency in foreign languages and good spoken language ranked first. The number of answer sheets was 48 , accounting for nearly $60 \%$, indicating that foreign language speaking ability is extremely important in international trade and international logistics activities.

\section{Quality Structure}

1) Professional ethics cultivation: It is necessary to pay attention to the shaping of personality qualities and the cultivation of craftsman spirit.

2) Humanistic qualities: It is required to pay attention to the study of humanities, science and technology, and social knowledge, improve social skills, and have strong communication, coordination and skills.

3) Teamwork and dedication: The logistics services have the characteristics of multiple subjects participating in multiple links and customer participation. Practitioners need to coordinate and communicate with others from time to time, and collaborate with upstream and downstream personnel.

4) High sense of responsibility and professionalism: The international logistics business is risky. Slightly
In order to grasp the importance of various import and export business capabilities in actual foreign economic exchanges, the respondents are asked to rank the different import and export business capabilities listed in the questionnaire according to their importance (Table II). inadvertent, the logistics may be transferred to customs and other national administrative departments for investigation. And the delay in logistics procedures may result in unimaginable trade losses. Therefore, international logistics practitioners must have a high sense of responsibility, and must strive for the excellence and responsibility.

\section{CONCLUSION AND SUGGESTION}

\section{A. Conclusion}

According to the analysis of the employers' questionnaire, the status quo of the professional ability of export-oriented logistics graduates and the expectations of the enterprise for graduates' professional ability were obtained, and the gap between the requirements of economic structure for the international economic and trade logistics professionals and that of the reality have been learned.

At present, the international logistics major in China's colleges and universities focuses on cultivating students' practical operation ability in the import and export process, while neglecting the training of international logistics business development capabilities. Employers have low 
evaluation on the international business development ability of graduates majoring in international logistics.

The employer is not very satisfied with the students' import and export business ability, and attaches the most importance to the English application ability of the import and export business.

Under the new normal economy, employers' requirements for international business development of international logistics graduates will become higher and higher.

\section{B. Suggestions for the Training of Outward-oriented and Application-oriented International Logistics Talents}

With the deepening of economic globalization, the demand for international logistics talents is more and more urgent, and the requirements put forward are getting higher and higher. Higher vocational colleges, as institutions for cultivating the applied international logistics talents, should have a more advanced vision and an international perspective, constantly improve the level of teaching and scientific research in international logistics, and cultivate a large number of high-quality skilled international logistics personnel in line with international practice and theory for international economic and trade development in China.

\section{REFERENCES}

[1] Cheng Yajun. Research on the Quality of Current Foreign Trade Practitioners - Based on the Changes in China's Trade Policy Environment [D]. Shijiazhuang: Hebei University of Economics and Business, 2013. (in Chinese)

[2] Ouyang Xiaoxun. Study on Quality Requirement and Cultivation Strategies for Application-oriented Talents of Advanced International Logistics [J]. Storage Transportation \& Preservation of Commodities, 2010, 32 (06): 178-180. (in Chinese)

[3] Cai Xiaoyong, Chen Chen, Yu Zipeng. The Study of Job Market Requirements for the International Business Capabilities of College Graduate from the Discipline of International Economics and Trade under the New Normal Economics - Based on the Analysis of the Questionnaire Survey Results [J]. Journal of Southwest China Normal University (Natural Science), 2015, 40 (10): 124-128. (in Chinese) 